\title{
District Health Information System on Maternal, Newborn and Child Health How Good Is It? A Case of Deli Serdang and Sumedang Districts
}

\author{
Anhari Achadi
}

\begin{abstract}
Valid data and information are critical for any health programs, in particular for planning, monitoring and evaluation purposes. District Health Information System is designed to produce routine data on process and output type of indicators at district level. This study, taking place at Deli Serdang and Sumedang districts, has its objectives as to learn about the current practice of DHIS, specifically looking at its process and the availability, quality and utilization of the data. Methods of data collection include in-depth interview with stakeholders at village, health facility and district levels, examination of existing forms at all levels as well as other documents and reports. Findings suggest that weaknesses of DHIS prevail at each level of the system. Complexity of the system has produced inaccurate and suboptimal the use of generated data and information.
\end{abstract}

Key words : District health information system, inaccurate data and information

\begin{abstract}
Abstrak
Data dan informasi yang valid sangat penting untuk program kesehatan, terutama untuk perencanaan, pemantauan, dan evaluasi. Sistem Informasi Kesehatan Kabupaten dibuat untuk menghasilkan data rutin tentang indikator proses dan output program kesehatan di tingkat kabupaten. Studi ini, yang dilakukan di kabupaten Deli Serdang dan Sumedang, bertujuan untuk mengetahui proses bekerjanya SIK Kabupaten, serta ketersediaan, kualitas dan penggunaan data yang dihasilkan. Pengumpulan data dilakukan dengan menggunakan beberapa cara, yaitu wawancara mendalam dengan para pemangku kepentingan di desa, fasilitas kesehatan, dan kabupaten, pemeriksaan formulir-formulir yang digunakan disemua tingkatan, dokumen lainnya, serta laporan. Temuan studi menunjukkan adanya kelemahan-kelemahan SIK dalam semua tingkatan. Karena kompleknya, sistem menghasilkan data dan informasi yang tidak akurat, dengan tingkat penggunaan yang rendah.
\end{abstract}

Kata kunci : Sistem informasi kesehatan kabupaten, data dan informasi yang tidak akurat 
Valid data and information are critical for any health program, in particular for planning, monitoring, and evaluation purposes. At national level Indonesia has carried out periodic surveys, such as Demographic and Health Survey and Basic Health Research (Riset Kesehatan Dasar). These surveys have produced a lot of outcome type of indicators, which are able to show health status of the people at national level. District Health Information System is designed to produce routine data on process and output type of indicators at district level. Data and information generated by this system are supposedly sufficient to serve the need of data for planning, monitoring, and evaluation purposes. The system also should be able to serve a specific need, such as monitoring the achievement of every district on the minimum service standards (MSS) on health, which was established in 2003 by the Indonesian Ministry of Health $(\mathrm{MOH})$, and then was updated in 2008. This set of minimum service standards has to be complied by health sector at sub-national level in providing health services for the community. The MSS is regulated through a Ministry of Health Decree No. 1457/MENKES/SK/X /2003 which was then replaced by the Ministry of Health Decree No. 741/MENKES/PER/VII/2008.1,2

In the MSS, a set of indicators is listed for the health authority to evaluate the success of their services, which also specifically cover maternal, neonatal, and child health $(\mathrm{MNCH})$, nutrition, and immunization. All of these developments have raised the issue on the quality of the country's health information system. The WHO's review on health information system (HIS) in selected countries shows weak routine HIS in Indonesia thus highlights the need to improve it. ${ }^{3}$ Numerous efforts have been taken by the $\mathrm{MOH}$, involving universities and international non-governmental institutions, such as UNICEF and GTZ. They are working to improve the sys- tem, but still much more to be done to improve the availability, quality, interpretation and utilization of data.

This study is aiming at getting a better understanding on the current practice of DHIS, using the two districts as 'case studies.' The specific objectives of the study were to assess the following, organized under the headings of Process, Availability, Quality and Utilization:

Process. The goal is to better understand the $\mathrm{MNCH}$ data collection process and systems. This includes an assessment of how data flows from the community level to the district level, what data collection instruments are used, and what are the main constraints and barriers. Availability. The goal is to review the availability of data at the district level. This includes a listing of data which is routinely collected by districts, the availability of data on the MSS indicators, and the main constraints and barriers in providing the data. Quality. The goal is to assess whether the data collected is of sufficient quality. This includes a review of data quality, what exists in terms of a data quality assurance process at the different levels, and the main constraints and barriers. Utilization. The goal is to assess how data is used at all levels of the system, and the main constraints and barriers to data use. This study has focused on indicators related to the MOH's MSS, e.g. antenatal visit 1 (K1), antenatal visit 4 (K4), skilled birth attendance coverage, high risk referral rates, neonatal visit 1 , neonatal visit 2 , coverage of child immunization, and coverage of nutrition programs.

\section{Method}

This study is qualitative in nature, and to arrive at the specific objectives, several methods were used, including the following: In-depth interviews with stakeholders at the village, health facility and district levels. Review of existing forms at the village, health facility and district levels. Review of documents and reports related to the

Table 1. Informants and Data Collection Methods (In Each District)

\begin{tabular}{lcc}
\hline Informants (\# resp)* & In-depth interview (\#) & Review of forms (\#) \\
\hline District level & & \\
Head of the District Health Office & $\mathrm{v}$ & \\
Head of Family Health Unit & $\mathrm{v}$ & $\mathrm{v}$ \\
Staff from Family Health Unit & $\mathrm{v}$ & $\mathrm{v}$ \\
Head of Data and Information Unit & $\mathrm{v}$ & $\mathrm{v}$ \\
Head of Planning Unit & $\mathrm{v}$ & $\mathrm{v}$ \\
Head of Community Development Committee & $\mathrm{v}$ & \\
and Environmental Health & & $\mathrm{v}(3 \mathrm{HCs})$ \\
Health center level & $\mathrm{v}$ & $\mathrm{v}(3 \mathrm{HCs})$ \\
Head of Health Center & $\mathrm{v}(3 \mathrm{HCs})$ & $\mathrm{v}(3 \mathrm{HCs})$ \\
Midwife Coordinator & $\mathrm{v}(3 \mathrm{HCs})$ & $\mathrm{v}(3 \mathrm{HCs})$ \\
Coordinator of Nutrition Programs & $\mathrm{v}(3 \mathrm{HCs})$ & $\mathrm{v}(3 \mathrm{HCs})$ \\
Coordinator of Immunization Programs & $\mathrm{v}(3 \mathrm{HCs})$ & \\
Village level & $\mathrm{v}(3 \mathrm{HCs})$ & \\
Village Midwives (2 midwives) & & \\
Private Midwives & &
\end{tabular}

*Number of respondent was one person per type of informant per district unless specified. 
DHIS (district health profile, etc.). Discussions with stakeholders to confirm and enrich findings.

The study began in the middle of 2008 with preparation activities including development of instruments and a plan for data collection. The instruments developed included in-depth interview guidelines and guidelines for reviewing the forms. Data collection was conducted in Deli Serdang and Sumedang Districts for about two months, starting from July 2008. Informants were stakeholders who involved in the HIS process from district to village level. The following table shows the informants interviewed in each district and the data collection method used for each informant. After the data were gathered and analyzed, the preliminary findings were then presented and discussed at the two districts involving health authorities and other stakeholders, to confirm the findings, intended as triangulation.

In-depth interviews were held with the stakeholders identified in Table 1. The in-depth interviews were approximately 45 to 60 minutes long. Informed consent was obtained from all respondents. The interviews were focused on the main objectives, which were to address the availability, quality, interpretation and utilization of data. Most interviews were completed with review of forms used at the village, health facility and district level, as noted in Table 1. Review of the forms was intended to cross check information across levels. District level meetings with the informants and other related stakeholders were conducted after the data analysis process was completed and some initial results were formulated. The meetings were intended to share the results with stakeholders, confirm the results of the study, and discuss proposed recommendations to improve the DHIS. All of these steps have taken place in 2009.

The interviews were audio-recorded and salient points from the interview were recorded on paper by the interviewers. Data analysis was mainly based on the interviewers' notes and complemented by checking to the audio records. Comparison of data across levels was conducted by comparing the figure written in village level document with the figure written in health centre level document for the specified villages and so on.

\section{Results}

\section{Data Collection Process}

Overall, there appears to be confusion among stakeholders on the DHIS data collection process, with different stakeholders sharing divergent opinions on how the process works. More detailed findings are below.

\section{Flow of Data Collection}

The flow of data collection begins at the village level, where routine and non-routine activities are conducted. Routine activities are conducted through the integrated post (posyandu), the 'Alert Village' activities (Desa Siaga), private midwives practices, and private clinics. Non-routine data collection activities refer to health activities that take place on a random or irregular basis, such as a head count of malnourished children, free of charge health care services etc.

Village midwives, or the health staff responsible for the village, are generally the ones tasked with recording the results of health activities at the community level. Usually, they are also responsible for collecting data from private midwives and private clinics, auxiliary health centers (Pustu and Poskesdes) as well as from the community, e.g. from health volunteers (kaders) (See picture 1).

In terms of how data from the private sector is collected, practices appear to vary. In some places the village midwives take the initiative to collect data from private midwives and clinics. In other places, it is the private midwives or the private clinics who actively report data to the village midwives or health staff responsible for the village. One private midwife stated that she reports data directly to the health center, using forms developed by the Indonesia Midwives Federation (Ikatan Bidan Indonesia/IBI). Whether the private midwives give the information to the village midwives or health centers or are asked for it may depend on the seniority of the midwives (i.e., a more senior private midwife may not see it as her responsibility to actively give her data to a lesssenior village midwife).

Once the village midwife collects the data, she turns the data over to program coordinators at the health center level such as the Bidan Koordinator (coordinator midwife). Program coordinators may also include an immunization coordinator, a nutrition coordinator, etc. Then, the health center program coordinators recapitulate the data reported by village midwives and submit the information to the District Health Offices. In addition, a separate morbidity form goes directly to the Sistem Pencatatan dan Pelaporan Terpadu Puskesmas (SP2TP, or the recording and reporting system for Puskesmas) by staff who responsible to record morbidity cases (from any cause).

It should be noted that by separating out the morbidity forms from the other forms means that at times, data which is related is separated into two pathways. This may mean that someone reviewing either of these forms would only be able to glean limited information about a patient's status (or trends, etc) despite the fact that different 'pieces' of information paint the full story. For example, the forms that the Bidan Koordinator recapitulates would include information such as complications related to pregnancy (i.e., ante-partum hemorrhage or eclampsia), but if this same mother also had malaria or hepatitis, this information is captured separately in the morbidity form. 


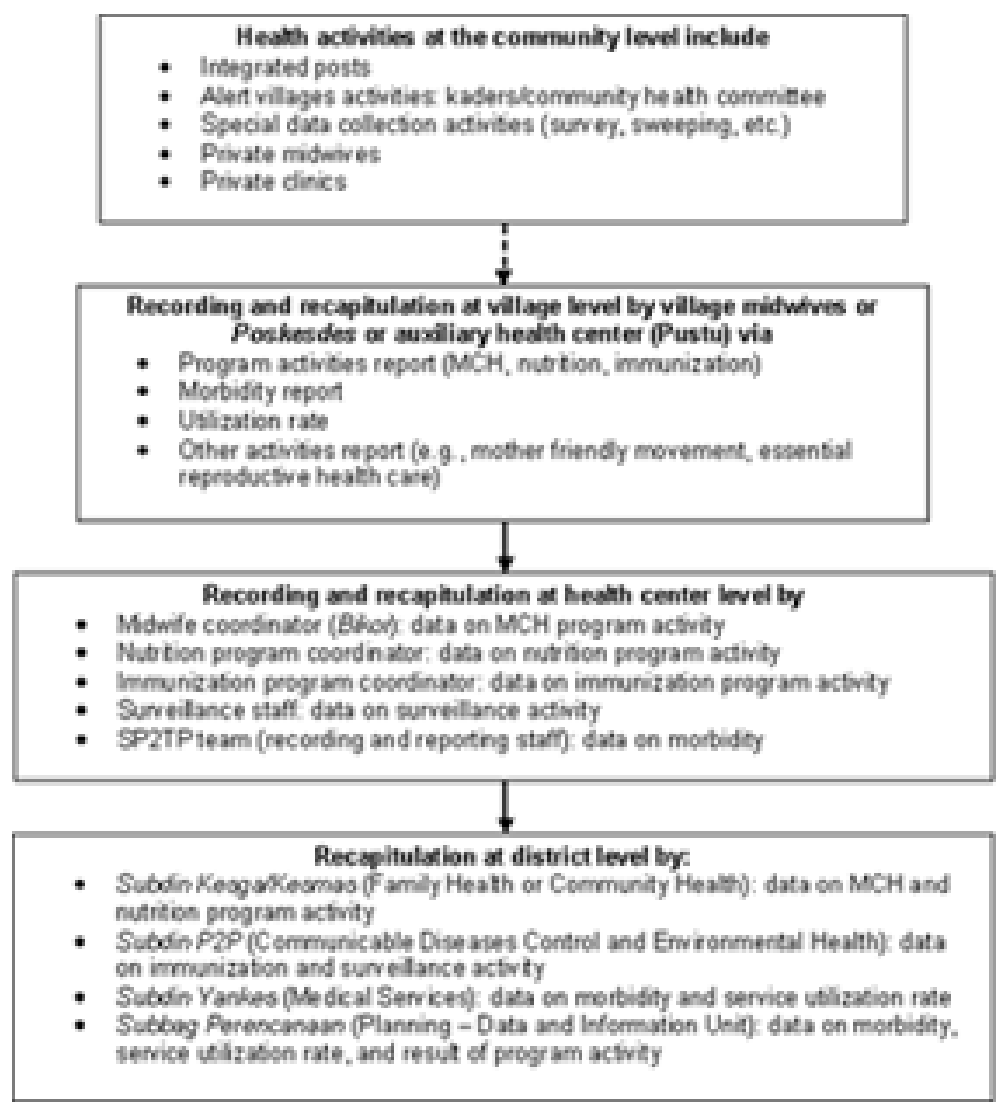

Picture 1. Data Collection Flow, District Level

Overall, interviewers received differing accounts from interviewees on how this process works. One informant stated that data from the health center is submitted to the subdins related to that particular program activity, and then the subdins report the data to the Data and Information Unit. Another informant, however, stated that the health center submits the data to both the subdins related to the programs activity, and also to other units such as the Data and Information Unit, Subdin of Planning and/or Subdin of Medical Services. At the District Health Office level, the subdins compile data from all the health centers under its authority. In one of the districts reviewed, the compilation by subdins is done manually, while in the other district, one subdin compiles the data manually and the others uses a computerized system. In addition to compiling data from health centers, the District Health Office also receives data from hospitals via the Sistem Pencatatan dan Pelaporan Rumah Sakit (SP2RS, or the recording and reporting system for hospital).

\section{Instruments Used}

In general, the instruments used for data collection can be divided into two types: 1) forms related to pro- gram activities (such as immunizations, maternal and child health, nutrition, etc); and 2) forms related to the morbidity report (such as number of malaria cases, dengue, hepatitis, etc).

Forms used at the village level generally contain more detailed information than those forms at the higher levels. Despite the fact that the detailed information is needed up to health centre level for the HC staff to compile the data (e.g. to avoid duplication), further consideration is needed to determine which information is really needed to be collected. It is clear that village midwives are responsible for many forms and/or books. It can be as many as 20 pages of forms each month. In addition, some forms are standardized (they are printed), while other forms or registers have been developed by the village midwives themselves and are handwritten so that they are at risk of alterations or random inputs. A number of informants suggested that the forms be simplified; since the forms overlap each other. For example, visit of a pregnant woman is recorded in many registers such as general visit register, pregnant women register, delivery cases register, and the cohort register. The midwife is also responsible for filling in the cohort register for babies, and forms related to nutrition and immunization prog- 
ram activities. In some places, the village midwives are also responsible for forms related to reproductive health care activities, mother friendly movement, etc.

There is no standardized form for private midwives and private clinics. In some areas, private midwives develop their own forms and registers, meaning that these can be vary from midwife to midwife. In other areas, private midwives use forms developed by IBI. At the health center and District Health Office levels, the forms are mostly recapitulation forms, including recapitulation forms on maternal and child health, nutrition, and immunization. Other forms at the health center level include the SP2TP forms, which consists of health center monthly morbidity report, monthly mortality report, monthly program activity result, etc.

\section{Work Load}

When stakeholders were asked for their opinion about the person who carries the heaviest burden of the health information system, the answers varied. Although some of the respondents stated that no one person shouldered the heaviest burden, but most informants named the village midwives as those with the heaviest recording and reporting responsibilities. However, the village midwives, while acknowledging that they were largely responsible for the bulk of data recording and reporting, did not appear to regard these activities as burdensome. Rather, it appeared the majority of midwives felt that recording and reporting data was their responsibility. Two midwives noted that their data responsibilities took time away from their responsibility to provide health services. Nearly all midwives, however, suggested that a simplification of forms and processes is needed.

Some informants noted that although village midwives shouldered the bulk of responsibilities for recording and reporting information, the program coordinators at the health center level were the ones who were ultimately responsible for the data, and would suffer the consequences if the data was not available or timely. Some informants stated that problems with the health information system were partly due to the lack of 'community participation' in the data collection process, thereby putting undue burden on village midwives to collect data directly from the community. However, it was unclear (even when asked directly) what informants meant by 'community participation', and what specific activities and roles or responsibilities they envisioned.

\section{Data Availability}

Regarding the Minimum Service Standards (MSS), this review found that only stakeholders at the higher levels (most stakeholders at the district level and some stakeholders at the health center level) could identify what the term 'MSS' referred to and how these were re- levant to their data collection activities. In both districts, the majority of informants who knew about the MSS stated that the indicators tracked at the district level complied with the MSS issued by the MOH, without any additions or reductions of the MSS indicators. Indeed, a comparison of available indicators at the district level (via an analysis of the district health profiles) with several indicators in the 2003 MOH's MSS show that the districts are able to provide most of the required indicators. However, there appears to be some missing information. For example, the two districts seemed to be lacking information on: the detection of high risk cases, the number of high risk pregnant women who require a blood transfusion, high risk pregnant women referred, pregnant women and neonates referred, under-five children with severe under-nutrition receiving treatment, coverage of under-five children receiving two capsules of vitamin $A$ a year, $0-7$ days hepatitis immunization rates, and the effectiveness of Posyandu programs (measured via under-five gained weight increase for children who visited and did not visit the Posyandu).

The MOH has issued the 2008 MSS to replace the 2003 version by reducing a number of indicators. Indeed, it appears some of the indicators that are frequently missing in the district heath profiles (i.e., those indicators which are more difficult for districts to collect) are not included in the revised version. There are some new indicators included in the revised MSS, such as the coverage of post-partum care and number of active Desa Siaga villages. There are also some changes in regards to the wording and definitions of some indicators in the revised MSS, which may help improve the DHIS. For example, the 2003 indicator 'high risk/complicated pregnant women managed' has now become 'pregnant, delivery, and post-partum women with complications managed.' This is because in the 2003 version, combining women with high risk pregnancies with pregnant women with complications into one indicator was misleading, as these two indicators have different meanings and implications. On the other hand, it appears some of the new 2008 indicators integrate previous 2003 indicators into one potentially more complicated indicator (See Table 2).

\section{Data Quality}

The review of data quality was done by assessing data accuracy, coverage and the timeliness of reporting. In regards to data accuracy, the evaluators worked to assess stakeholders' understanding of selected indicators, including the numerator and denominator of the indicators.

\section{Accuracy}

Regarding the accuracy of the reports, this review 
Table 2. Indicators Changes from the 2003 MSS to the 2008 MSS

\begin{tabular}{|c|c|}
\hline 2003 MSS & 2008 MSS \\
\hline High risk/complicated pregnant women managed & Pregnant, delivery, and post-partum women with complication managed \\
\hline High risk/complicated neonates managed & Neonates with complication managed \\
\hline $\begin{array}{l}\text { Coverage of under-five children receiving } 2 \\
\text { capsules of vitamin A a vear }\end{array}$ & $\begin{array}{l}\text { Coverage of services for under-five children (definition of services includes receive } \\
\text { monitoring of growth every month, early growth and development stimulation. }\end{array}$ \\
\hline $\begin{array}{l}\text { Coverage of early growth and development detection } \\
\text { for under-five and pre-school children }\end{array}$ & detection and intervention, and receiving 2 doses of vitamin A per year) \\
\hline
\end{tabular}

Table 3. Comparison Between Data Recorded at Village Level and at Health Center Level

\begin{tabular}{|c|c|c|c|c|}
\hline Indicators & Village & $\begin{array}{l}\text { Data recorded } \\
\text { at village level }\end{array}$ & $\begin{array}{l}\text { Data recorded } \\
\text { at HC level }\end{array}$ & Comment \\
\hline \multirow[t]{4}{*}{ K1 } & $\mathbf{A}$ & $89(53 \%)$ & $149(89 \%)$ & Increase in absolute number and proportion \\
\hline & B & $31(64.5 \%)$ & $43(89.5 \%)$ & Increase in absolute number and proportion \\
\hline & C & $95(66.2 \%)$ & $97(50 \%)$ & Increase in absolute number \\
\hline & & & & Reduction in proportion \\
\hline \multirow[t]{4}{*}{ K4 } & A & $63(38 \%)$ & $93(56 \%)$ & Increase in absolute number and proportion \\
\hline & B & $33(68.7)$ & $37(77.1 \%)$ & Increase in absolute number and proportion \\
\hline & $\mathbf{C}$ & $110(77.5 \%)$ & $113(58.25 \%)$ & Increase in absolute number \\
\hline & & & & Reduction in proportion \\
\hline \multirow[t]{3}{*}{ SBA } & A & $57(36 \%)$ & $104(65.8 \%)$ & Increase in absolute number and proportion \\
\hline & B & $23(50 \%)$ & $23(50 \%)$ & Consistent \\
\hline & C & $119(91 \%)$ & $110(59.46 \%)$ & Reduction in absolute number and proportion \\
\hline KN1 & A & $57(38 \%)$ & $104(68.8 \%)$ & Increase in absolute number and proportion \\
\hline \multirow[t]{3}{*}{ KN2 } & $\mathbf{A}$ & $57(38 \%)$ & $109(68.8 \%)$ & Increase in absolute number and proportion \\
\hline & B & $24(52.3 \%)$ & $25(55.6 \%)$ & Increase in absolute number and proportion \\
\hline & C & $119(98.3 \%)$ & $106(59.22 \%)$ & Reduction in absolute number and proportion \\
\hline
\end{tabular}

Notes: data presented are excluding villages with missing information; percentage of coverage is written in parenthesis; shaded row refers to consistent data between the two levels

found differences in understanding the definition of certain indicators, and the way in which the indicators are to be collected and/or recorded. For example, indicator for the forth antenatal care visit (K4) was recorded in various ways. In one case, a midwife mentioned that $\mathrm{K} 4$ refers to antenatal visits conducted more than twice, while other midwives mentioned it refers to one visit during the first trimester, one visit during the second trimester, and two visits during the third trimester. The criteria which should be met for each visit also varied, e.g. whether two tetanus injections should be fulfilled to claim K4. Criteria for delivery assisted by a skilled birth attendant (SBA) were also similarly inconsistent. This was shown by the fact that one midwife did not know whether a case in which the midwife arrived after delivery could be counted as SBA.

Another example is regarding the definition of maternal death. Nearly all informants at the health center and village level could not precisely and completely answer when asked about the definition of maternal death. Most of them said that maternal death refers to deaths related to the delivery process. Death during pregnancy or postpartum was not mentioned by the health providers. This may explain the pattern of maternal deaths reported in the district health profiles, which mostly refer to deaths during delivery. Only a small proportion of deaths recorded in the district health profiles occurred during the postpartum period and no death was reported during pregnancy.

Another problem was in regards to diseases coding and specifically the international code of disease classification (ICD). In some of the forms provided by the $\mathrm{MOH}$, health providers are requested to use the ICD. However, it appears not all providers are familiar with these codes or how to accurately use them. Other than problem with numerator, it appeared that there were also different data sources used for determining denominators. For example, some informants used estimations made by the Central Bureau of Statistics/BPS (CBS) as the denominator while others used actual local data as the denominator. The reason for using actual data as the denominator appears to be because many assume that the CBS estimation is too high, and therefore targets will not be achieved if they use the CBS estimation. In response to the interviewers' question whether there is any effort done to ensure that all health providers have same understanding on the MSS indicators, most informants stated that this was done through monthly meetings, both at health center and District Health Office level. However, there was no event conducted specifically to build a com- 
mon understanding of the indicators.

An analysis of data recorded at the village level as compared to the health center level showed serious discrepancies between the two. Detailed information about the comparison between village data and health center data is presented in Table 3. From the tables a serious discrepancy is seen, both in absolute numbers and in the percentages, between the data obtained from a midwife in one village and the recapitulation data at the health center for that village. Discrepancies were also apparent between the health center and District Health Office data for the specified health center. Further, district recapitulation data is also different with what is written in the district health profile. These inconsistencies occurred in both districts. Further exploration is needed to discover possible explanations for these inconsistencies.

One possible reason for these discrepancies might be the data management process, which is conducted manually. The review saw that at the health center level, four of the six health centers reviewed managed their data manually. At the District Health Office level, most of the subdins manage the data using computers, with only a few subdins manage it manually. Within the recapitulation data calculated manually, a great deal of miscalculation was found for data presented in percentages. In addition to the problem noted above with manual entry, another reason for the differing data may be the different data sources used as the target for the denominators. Further, during discussions with stakeholders, they suggested one possible explanation for the discrepancy between village level data and recapitulation data at the health center level for the specified villages is that the additional cases may have been added by the health center itself, rather than having been recorded by village midwives. However, overall there is no clear explanation for why these discrepancies exist. Inconsistencies were also found in the ways in which the informants filled out the forms. For example, in some forms informants used either a 0 or '-' mark or left blank some cells, intending this to reflect the same meaning (i.e., no case).

Particular to maternal health indicators, attention is needed on the reporting of the number and treatment of pregnancy-related complications. Forms at the village level only cover the detection of high risk cases (by health providers and by community), with no information on number and type of complication cases. Further, most cells for the high risk cases are left blank by the village midwives. At the health center level, the information on high risk cases is usually filled with ' 0 ' (meaning no cases were found). A review of LB1 (monthly form) at the district level shows that rows for information on the number of direct obstetric cases such as eclampsia, hemorrhage and sepsis are left blank. This suggests the need to identify the cause of this situation, whether it is caused by the lack of understanding on the indicator or the un-availability of data, whereas specific information on the indicator is very important.

\section{Coverage}

Coverage refers to how broadly a program captures data from its catchment area, and if the program is reaching its intended targets. Generally, informants stated that there was no problem in terms of program coverage and that for most of their activities, they felt confident they were reaching their intended coverage targets. The informants noted their efforts to ensure high coverage, including: picking up reports from private midwives, conducting home visits, and initiating special efforts such as free of charge services, kaders mobilization, involving village staff to mobilize the community, etc. Informants mentioned a number of indicators which they felt usually fell short of their targets, including K4 (ANC visit 4), KN2 (neonates visit 2), skilled birth attendance, high risk detection by community, and hepatitis B immunization for early neonates. In some cases, when targets were not achieved or coverage appeared low, informants suggested that this was due to the high (and sometimes inaccurately so) estimates from the Central Bureau of Statistics/BPS (CBS), which determines targets based on averages of national statistics. Informants therefore felt it was more accurate to use real targets specific to their catchment areas, rather than relying on the national statistics for their district level targets. Informants were forthcoming in admitting that because they felt the targets were so unrealistic they sometimes manipulate coverage rates for the health center's programs.

\section{Timeliness}

Most informants said that delays in data submission were a problem. Informants noted that delays usually begin at the village level. In an effort to turn in their report in a timely manner, some Bikors leave blank the rows corresponding to the villages which have delayed reports. Then, when the information finally is submitted, she adds the previous month's data to the current month's report. Others fill in the rows with a best-guess estimate and adjust the estimates for the next month based on the cumulative number reported that month. Both practices might cause a confusion in assessing the figure by time. As noted above, informants stated that it was the program coordinators at the health center level who were ultimately responsible for the data, and would suffer the consequences if the data was not available or timely. A number of efforts have been initiated to overcome the problem of data submission delays, such as giving warnings to health providers who submit their report late, and reminding village midwives about deadlines in advance. 


\section{Interpretation}

At the health center level, data interpretation is done by the head of the health center, and sometimes used for feedback during the monthly meetings (lokakarya mini bulanan). For this process, the head of the health center is assisted by the program coordinators. Some of the informants interviewed stated that there are no special guidelines for data interpretation, and that data interpretation depends on the perspective and abilities of the head of the health center. Data interpretation at the District Health Office level is mostly done by each subdin, as a basis to give feedback to the health centers. In developing the district's health profile, the Data and Information Unit collects all information from subdins, drafts the profile, and presents the draft in a meeting attended by representatives from all subdins. In the meeting, data is interpreted with inputs from all participants. Thus interpretation of the data from each subdin is not only done by the subdin related to the data but a broader consensus.

From a review of the district health profiles, it appears that improving the District Health Office's ability to interpret the data is critical, with a focus on issues such as how to compare data over time and across areas, and how to assess improvement in coverage or an increase in the number of cases of a certain indicator. For example, it appears that districts generally explain an increased number of reported cases of a disease or deaths as a result of improvements in recording and reporting practices, rather than taking a closer look if this is really the case. It is also a common practice that the DHO comparing number of cases (e.g. maternal death cases) rather than comparing rate.

\section{Data Quality Assurance Process}

In general, there are no standardized guidelines for conducting a data quality assurance process. The process is performed differently in different places, and appears to be mostly based on the perspective and abilities of the health center's management. For example, in one health center, a team (consisting of the head of the health center, program coordinators, etc.) conducts supervision visits to all village midwives in the health center's catchment area to re-check and validate the midwives' reports. In another health center, the re-check process is done in the health center itself when reports are turned in. Another health center performs quality assurance efforts by conducting home visits to validate reports that a delivery was assisted by a skilled birth attendant; however, this practice was not found in the other health centers reviewed. Overall, it appears that data reported by village midwives are rarely validated by program coordinators or health center staff, and when there are validation activities, these appear to be conducted on an ad-hoc basis.
Data validation activities at the health center level to ensure that there is no duplication of data are rarely (if ever) conducted. Before data is sent to the District Health Office, the head of the health centers are responsible for checking the accuracy of the reports. However, it appears this is not done in any systematic or rigorous way. The head of the health centers report they often do not have time to check the report adequately because of the deadline, and therefore they sign the reports without validating the data. At the District Health Office level, efforts to validate data are rare and not a routine activity. Validation is done only if there is any 'odd' data, e.g., data that is hugely different with the previous data or data that is not in line with other related data (e.g. number of vaccines used as compared to the number of children immunized). The decision of what data to be used is often made randomly, based on the data sources regarded as the most valid according to staff.

\section{Data Utilization}

At the health center level, data is usually utilized as a basis for the report to the District Health Office. Data is also sometimes used for providing feedback to health providers at the health center level, and other sectors in the health center's catchment area. The feedback is given to health providers through health center monthly miniseminars or staff meetings, or at the village midwives' meeting. Health providers receiving feedback are mainly those who work in the health center. Feedback to private midwives and other health professionals in private practice is rare. Feedback for other sectors (e.g. head of subdistrict, etc.) is delivered either formally in monthly meetings or through other informal events (e.g. communication directly to the head of the sub-district). In general, informants at the health center and village levels stated that they faced no considerable barriers in using data to provide feedback.

At the District Health Office level, data is mainly used as the basis for planning the next program (including for DTPS), evaluating achieved targets, and developing district's health profile which in turn is often used by the District Health Office as an accountability report, e.g. to the District Planning Board (Bappeda). Externally, the District Health Office uses their data to support research and provide information to organizations interested in specific health topics.

\section{Constraints, Challenges and Lessons Learned}

Overall, as noted previously, several barriers were mentioned in the implementation of the DHIS. The main challenge appears to be the number of reports, which are quite numerous and therefore burdensome. There is also no specific explanation or instruction about which unit is responsible for the information system at the health cen- 
ter level. Informants also mentioned that the non-existence of punishment or penalties for delays in recording and reporting process were also barriers to an effective DHIS.

At the community level (including Pustus, Desa Siaga, private midwives and private clinics), a big challenge appears to be unclear expectations on the part of the health centers about what the communities should and should not provide. For private midwives and private clinics, a challenge is the non-existence of policies regarding standardized recording and reporting practices for private providers, including the reporting flow and their role within the structure. At the village level, again the challenge is the large number of forms, and the lack of clear guidance on the flow of data collection (for example, do village midwives pick up information from private midwives, or do private midwives submit data directly to the village midwives or the health center?). Other barriers mentioned are the lack of transportation fees for home visits, staff turnover, and the reluctance to do recording and reporting because village health providers felt that it is more important to do their main work of providing services. At the health center level, challenges mentioned included the lack of personnel to do complete data checks, and the unavailability of transportation fees and vehicles for these data checks. Moreover, the unavailability of computers at the health center level is a challenge, because staff must enter data manually and thus may make more mistakes than if this system was computerized. However, even at the health centers where computers are available, it appears most personnel are not able to operate the computers, or the small number of computers results in competition over use towards the end of the month when reports are due. At the District Health Office level, computer issues also appear to pose challenges, mainly because there are staffs that are not able to operate the computers and therefore data recapitulation is frequently conducted manually. Other challenges include the lack of coordination between subdins, as there is no one person assigned to be responsible for data in each subdin, and the lack of human resources to check the data.

Which data sources are used for the denominator to calculate the indicators needs to be reviewed. Overall, informants considered the estimate from the BPS as too high. However, there is no generally accepted alternative source which districts can use, or which take into account the specific context of each district. It is critical to sensitize district stakeholders at all levels about the importance of having accurate information, with a deemphasis on meeting targets. To ensure the reliability of measurements, it is clear that work is needed to help stakeholders better understand the definition of key indicators and how to accurately record them. Excluding considerations about data quality, it appears that districts are able to provide most of the indicators in the MOH's MSS. Yet across all levels, there is little evidence to suggest the data is being used in order to improve programming or inform the health services provided.

\section{Discussion}

Findings from the study suggest that there has been no significant improvement in the conduct of the health information system in Indonesia. The main problems are the complexity of the system, low accuracy of information generated by the system and suboptimal used of the information. The complexity of the HIS reflects the unclear linkages among different subsystems of the HIS. This finding is similar to result of review by WHO on HIS in selected countries including Indonesia. The WHO's review suggests that the continuing breakdown of the routine HIS in Indonesia is due to misunderstanding of decentralization process and a lack of central authority. ${ }^{3}$ The unclear linkage among different sub-systems in the DHO theoretically could be overcome by creating a clear distinction of responsibility of each unit in the DHO to provide data for the MSS indicators. Therefore it is expected that there will be no overlapping information across units in the DHO. From the interviews, it is stated that the DHO uses MSS from the $\mathrm{MOH}$, as a reference in providing information through the DHIS. However, duplication of information across sub-units remains and there has been no clear effort to make a 'one-door' HIS. This finding is also similar to the finding of assessment conducted by Boediharjo et.al which also highlights the need to simplify the system to have an integrated recording and reporting system. ${ }^{4}$ Another WHO report stated that HIS also have been fragmented by the demands of disease-focused programs, donor requirements, and international initiatives. This may easily overwhelm the system and data are often being collected without being analyzed critically. ${ }^{5}$

From another point of view, disregard the double burden might be faced by the system, duplication of information, which can be seen as trying to capture information through more than one method, not only better than no information at all but it also can be used to validate the information gathered by each method (sub-unit). So the clear distinction of which unit responsible for which indicator does not mean that data collection should only be done by the responsible unit. In situation where same data is collected by more than one unit (e.g. TT immunization for pregnant women -collected by both the $\mathrm{MCH}$ and Immunization Unit), there should be a validation process to make one mutually exclusive and complete data. The condition needed to have one mutually exclusive data is a clear identification of each case recorded so that record linkage can be done. ${ }^{6}$ 
The low quality of the HIS is mainly due to the unreliable information gathered through the system. This includes information on numerator and denominator of some indicators. Understanding of definition of each indicator varied. This might be caused by the inexistence efforts to generate uniform understanding across health providers on each indicator. In addition, there is a need to have a clearer guideline to fill in the form for each MSS indicator. The guideline should also accommodate some possible conditions and how to record those specific conditions, e.g. whether a delivery which was fully assisted by a TBA and the midwife arrived after the delivery process should be recorded as skilled birth attendance. Other than providing a clearer guideline, a nonblaming culture should be encouraged since the misspractice of data recording and reporting might be influenced by a blaming culture. The unreliable understanding and practice on recording each indicator would compromise the quality of the evidence base used for decision making since errors in the recording are likely to be aggregated and reported up through the system. ${ }^{7}$

Another problem related with the quality of information generated by the DHIS is the lack of quality assurance process. There has been no document can be used by each stakeholder in the system in ensuring the quality of information generated by the system. Most stakeholders conducted the quality assurance process based-on their own understanding so that it varied from place to place. Current knowledge suggests the necessity of a clear quality assurance in any information system. The process might include, e.g. visits to service delivery sites and health centre, etc., to verify the accuracy, timeliness, and completeness of reported data. ${ }^{7}$

The review shows that the data to some extent have been utilized following the routine health system, e.g. to provide feed back to health providers through monthly meetings at health centre, to develop district health profile, for program planning, etc. It seems that the data have been used optimally. However, there is still a concern related with data interpretation, such as how to compare data over time and across areas and how to assess improvement. This problem may lead to inappropriate program planning.

\section{Conclusions}

This study reveals that weaknesses prevail at each level of the system, presenting different kinds of problems. In summary: There is no routine activity to build a common understanding of the DHIS and the indicators in particular. The data collection flows from the community up to the district level are inconsistent. There are many forms from the DHO of which overlap. Health centers and village midwives also develop specific books and forms, adding an additional burden to the system.
While most of the MSS indicators are well tracked, some indicators are not able to be documented or collected. The reliability of data gathered through the system is questioned. There were different understandings related to the numerator and denominator of some indicators. There were also incorrect practices in terms of recording some indicators. There are inadequate quality assurance mechanisms in place for cross-checking and validating data. When data checks do occur they are adhoc. There is still a concern related with data interpretation. The ability of program managers in comparing data over time and across areas and in assessing improvement is still inadequate. Data is utilized primarily to provide feedback for health providers and program planning. The feedback given is generally focused on coverage levels and routine reporting, with only a small portion of feedback related to data quality.

\section{Recommendations}

The main recommendation is for the District Health Office to simplify and improve the DHIS from the topdown. This could be done by: 1) reducing the number of indicators by referring to the new MSS indicators set by the $\mathrm{MOH}$, although some new indicators might need to be re-visited; 2) separating out indicators which can be recorded and reported routinely, and indicators which can be collected occasionally; 3) simplifying data recording and reporting processes into a few select forms; and 4) improving data coverage by involving the community in the recording and reporting processes. Detailed recommendations for each level are as follows: for community; build a consistent understanding of the indicators and recording practices for all involved in community reporting. Clarify the roles and responsibilities of the community, addressing issues such as: Who does 'community' refer to, individuals or representatives of individuals? What should be reported? How should the reporting be performed, is it written or verbal? What is the timetable for reporting? To whom should they report to? How will they receive feedback? For village; raise awareness of health providers on the importance of data accuracy and quality. Build a consistent understanding of the indicators and recording practices for all involved in village reporting, including producing clear guidelines. Simplify and standardize forms at the village level, including providing standardized forms for all village midwives, including private midwives as well as private clinics. For health centers; Raise awareness of health providers on the importance of data accuracy and quality. Build a consistent understanding of the indicators and recording practices for all health staff, including producing clear guidelines. Institute regular data quality checking processes. Improve the ability of staff to conduct data quality checks. Improve the ability of staff to manage data, in- 
cluding training in computer processes. Improve the ability of staff to analysis and interpret data. Improve the ability of staff to feedback data to the appropriate sources. Assign one or two staff to be responsible for data at the health center level. For District Health Office; raise the awareness of health providers on the importance of data accuracy and quality. Build a consistent understanding of the indicators and recording practices for all health staff, including producing clear guidelines. Improve the ability of staff to conduct data quality checks. Institute regular data quality checking processes. Improve the ability of staff to manage data, including training in computer processes. Improve the ability of staff to analysis and interpret data. Improve the ability of staff to feedback data to the appropriate sources. Assign one or two staff to be responsible for data at the district level.

\section{Acknowledegements}

The author and his team are indebted to many institutions and people, especially District Health Office in Deli-Serdang and Sumedang, and Puskesmas (Health Center) in these two districts, and all colleagues in these institutions, who have been very helpful, and have provided data, information, and their invaluable opinion. We have enjoyed frank discussions with midwives at the villages, doctors and other health center personnel, and also with district health management, to whom we would like to express our gratitude. The author also especially wants to express great appreciation to his colleagues, i.e. SN Qomariyah, Trisari Anggodowati, Poppy Deviany,and Nony Parmawaty who have assisted collecting and analyzing data. This study is financially supported by HSP/ John Snow Training and Research Institute through
Center for Family Welfare Faculty of Public Health University of Indonesia (PUSKA FKMUI).

\section{References}

1. Depkes RI. Standar pelayanan minimal bidang kesehatan di kabupaten/kota: Keputusan Menteri Kesehatan RI Nomor 1457/Menkes/SK/X/2003 (minimum service standards for health sector at district/municipality level). Jakarta, Indonesia: Setjen Depkes RI; 2003.

2. Depkes RI. Standar pelayanan minimal bidang kesehatan di kabupaten/kota: Keputusan Menteri Kesehatan RI Nomor 741/Menkes/Per/VII/2008 (minimum service standards for health sector at district/municipality level). Jakarta, Indonesia: Setjen Depkes RI; 2008.

3. WHO. A review of health information system (HIS) in selected countries: Indonesia. Accessed at www.who.int/entity/healthmetrics/library/indonesia_05apr

4. Budiharto M, Soewarta K, Harimat H. Upaya penyempurnaan sistem informasi kesehatan tingkat kabupaten/kota: studi kasus di Denpasar, Kabupaten Tabanan, Kupang, dan Kabupaten Belu. Puslitbang Sistem dan Kebijakan Kesehatan. Diunduh dari: http://www. litbang. depkes. go.id/ download seminar/ desentralisasi 6-80606/MakalahMartuti.pdf.

5. WHO. Strengthening of health information system. Report by the secretariat of the sixties world health assembly [edisi 2007]. Diunduh dari: http://www.who.int/gb/ebwha/pdf_files/EBSS-EB118-2006-REC1/english/Res/listing/b118_r4-en.pdf.

6. Machado CJ. A literature review of record linkage procedures focusing on infant health outcomes. Cad. Saude Publica, Rio de Janeiro; 2004, 20(2):362-371. Diunduh dari: hhtp://www.scielo.br/pdf /csp/v2on2/03.pdf.

7. Measure Evaluation. Data quality assurance for routine health information system, Moni-toring \& Evaluation Forum. Accessed at http://www.cpc.unc.edu/measure/ networks/rhino/dqa-forum. 